\title{
JUURNAL.RU
}

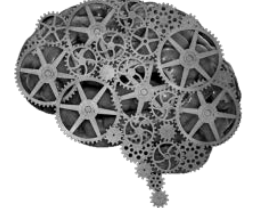

COMPANY GROUP "INTELLEKT"

\author{
Максимова М.Н., Михайлова Л.Р. \\ ГБОУ ВПО «Казанский государственный медицинский \\ университет» Минздрава России \\ Казань, Россия
}

doi: 10.18411/lj2016-7-1-15

idsp 000001: lj2016-16-1-15

\section{Применение современных информационных технологий при оказании услуг центрами занятости населения г. Казани}

\begin{abstract}
Актуальность выбранной темы исследования определяется необходимостью изучения применения и совершенствования процесса информатизации отрасли социальной защиты, труда и занятости. В частности постоянно имеется необходимость в исследовании применения, проблем и совершенствования современных информационных технологий в работе центров занятости населения (ЦЗН) при оказании социальных услуг.
\end{abstract}

Объект исследования - современные информационные технологии, применяемые в работе ЦЗН г. Казани при оказании социальных услуг.

Цель исследования - проанализировать применение современных информационных технологий специалистами и клиентами ЦЗН г. Казани.

Методология исследования:

- интервью с сотрудниками ГКУ «ЦЗН Ново-Савиновского района» и ГКУ «ЦЗН Приволжского района» г. Казани;

- анкетный опрос 60 клиентов ГКУ «ЦЗН Ново-Савиновского района» и ГКУ «ЦЗН Приволжского района» г. Казани;

- изучение и анализ нормативно-правовой базы и научноисследовательских источников литературы по теме исследования. 
Задачи исследования:

1. Изучить информационные технологии, применяемые в работе ЦЗН.

2. Проанализировать проблемы, возникающие при использовании информационных технологий в работе ЦЗН.

3. Исследовать отношение клиентов ЦЗН к информационным технологиям, применяемым в работе ЦЗН.

4. Исследовать отношение сотрудников ЦЗН к информационным технологиям, применяемым в работе ЦЗН.

5. Сформулировать перспективы модернизации информационных технологий, применяемых в работе ЦЗН при оказании социальных услуг.

При предоставлении государственных социальных услуг безработным гражданам и работодателям в ЦЗН используются следующие программные продукты: Катарсис, 1-С предприятие, 1-С зарплата, АП Континент, СУФД, АЦК, ТАКСНЕТ, ИАС МДБУ, электронный магазин, Единая информационная система в сфере закупок OOC, Консоль заказчика, VipNet Деловая почта, электронный документооборот, ИСКО, Касперский, Консультант +, Банковский Online-klient, Офисные программы (WORD, Excel, Outlook).

Информационные технологии, используемые клиентами ЦЗН: Портал государственных и муниципальных услуг Республики Татарстан (РT); официальный сайт ЦЗН; общероссийская база вакансий «Работа в России»; система электронной очереди; терминал вакансий; электронный банк вакансий; мобильные офисы ЦЗН.

На Портале государственных и муниципальных услуг РТ в разделе «Труд и занятость» предоставляются следующие виды услуг:

1. Постановка на учет граждан в поиске подходящей работы. С помощью данного сервиса можно получить информацию о порядке предоставления услуги, подготовить документы для постановки на учет в поиске подходящей работы, скачать бланк заявления о предоставлении данной услуги, а также записаться на прием к специалисту ЦЗН для личной подачи комплекта документов через личный кабинет пользователя. 
2. Организация профессиональной ориентации граждан. С помощью данного сервиса можно ознакомиться с перечнем документов для получения услуги, скачать бланк заявления о предоставлении услуги, записаться на прием к специалисту ЦЗН для подачи готового комплекта документов через личный кабинет пользователя. Также указаны адреса ЦЗН г. Казани, Набережных Челнов, Альметьевска, Зеленодольска, Чистополя.

3. Содействие гражданам в поиске подходящей работы. Данный сервис производит перевод на Портал Министерства труда, занятости и социальной защиты РТ для подачи заявления для постановки на учет в поиске работы.

На официальном сайте ЦЗН представлена следующая информация: контактная информация, нормативно-правовые документы, статистические и аналитические материалы, ответы на актуальные вопросы, интернет-приемная, база вакансий, информация для работодателей. Имеется Интернет-приемная.

Также ведет свою работу официальный информационный портал «Работа в России» (www.trudvsem.ru), который содержит сведения о вакантных рабочих местах и гражданах, обратившихся в органы государственной службы занятости населения всех субъектов РФ, и позволяет работникам самостоятельно осуществлять подбор подходящей работы в любом регионе России, а работодателям - работников, в том числе желающих трудоустроиться в других регионах. На этом портале размещены справочные и информационноаналитические материалы, адреса всех органов исполнительной власти субъектов РФ, осуществляющих переданные полномочия в области содействия занятости населения, государственных учреждений - ЦЗН, нормативные документы, наиболее характерные и часто повторяющиеся вопросы и ответы и т.д.

Система электронной очереди позволяет оптимизировать управление потоками посетителей, улучшает качество обслуживания клиентов, избавив их от утомительного ожидания в «живой» очереди, дает возможность предварительной записи. При этом клиенту обязательно будут оказаны услуги и вне электронной очереди, по обращаемости. 
Для оказания государственных услуг в органах службы занятости населения РТ используются 28 мобильных офисов центров занятости населения (МОЦЗН, Мобильные офисы). Работа МОЦЗН организуется на основании планов графиков, которые разрабатываются ЦЗН и размещается на стендах ЦЗН и на интернет - портале.

На базе Мобильных офисов проводятся следующие целевые мероприятия: предоставление государственных услуг по информированию о положении на рынке труда в РТ, профессиональная ориентация граждан в целях выбора сферы деятельности, трудоустройства, профессионального обучения; организация ярмарок вакансий и учебных рабочих мест; содействие самозанятости безработных граждан; содействие гражданам в поиске работы, а работодателям в подборе необходимых работников и др.

Проведённое исследование на базе ЦЗН Ново-Савиновского района и ЦЗН Приволжского района г. Казани дало следующие результаты, проанализированные нами.

В анкетном опросе приняли участие 60 клиентов с целью оценки применения ИТ в работе ЦЗН, из них: 52\% - женщины и 48\% - мужчины. Средний возраст респондентов от 30 до 39 лет.

Были изучены пути получения гражданами информации о предоставлении государственных услуг в ЦЗН. Для этого респондентам был задан вопрос: «Откуда Вы узнали об услугах центров занятости населения?».

Большинство респондентов узнало об услугах ЦЗН через знакомых / родственников / друзей (65\%). Также респонденты отмечают, что необходимую информацию они получили через Интернет (50\%). Таким образом, можно сделать первичный вывод о достаточной степени информированности населения об услугах ЦЗН с использованием средств массовой коммуникации.

Мы изучили мнение клиентов учреждения относительно следующих информационных технологий: система электронной очереди; терминал вакансий; официальный сайт ЦЗН; Портал государственных и муниципальных услуг РТ.

Необходимость электронной очереди отметили 95\% респондентов в обоих учреждениях. Это и понятно, учитывая возраст обратившихся в ЦЗ. 
Степень удовлетворенности граждан системой электронной очереди достаточно высока: 85\% опрошенных отметили, что организация системы электронной очереди их полностью устраивает; 15\% отметили, что бывают сбои при работе системы (например, отсутствие талонов из-за ошибки в терминале; отсутствует инструкция пользования системой; выходили талоны с ошибкой кода).

При обращении в ЦЗН граждане могут воспользоваться информационным терминалом вакансий для расширения возможностей трудоустройства. Свое пользование данным устройством подтвердили всего $72 \%$ респондентов. По поводу информации, представленной в терминале вакансий, 45\% респондентов отметили, что перечень полон и актуален, $45 \%$ указали, что часть информации устарела, а $15 \%$ опрошенных ответили, что затрудняются ответить.

О существовании официального сайта ЦЗН знают 90\% респондентов, однако $30 \%$ опрошенных никогда не посещали данный ресурс.

На вопрос: «Какие разделы Вы чаще всего посещаете на официальном сайте ЦЗН», - опрошенные указали такие разделы, как контактная информация $33 \%$, документы, необходимые для постановки на учет в ЦЗН - 33\%, график ярмарок вакансий $-21 \%$, статистика, аналитика - $8 \%$, нормативные документы $5 \%$.

О возможности записи на прием к специалисту ЦЗН через Портал государственных и муниципальных услуг РТ знают $80 \%$ респондентов.

Согласно проведенному опросу, 95\% граждан положительно относится к деятельности ЦЗН, направленной на развитие применения современных информационных технологий.

Количество обращений через Портал государственных и муниципальных услуг РТ растет. Динамика обращений граждан через Портал государственных и муниципальных услуг РТ в ЦЗН Ново-Савиновского и Приволжского районов с января по май 2016 года представлена на рис. 1. 


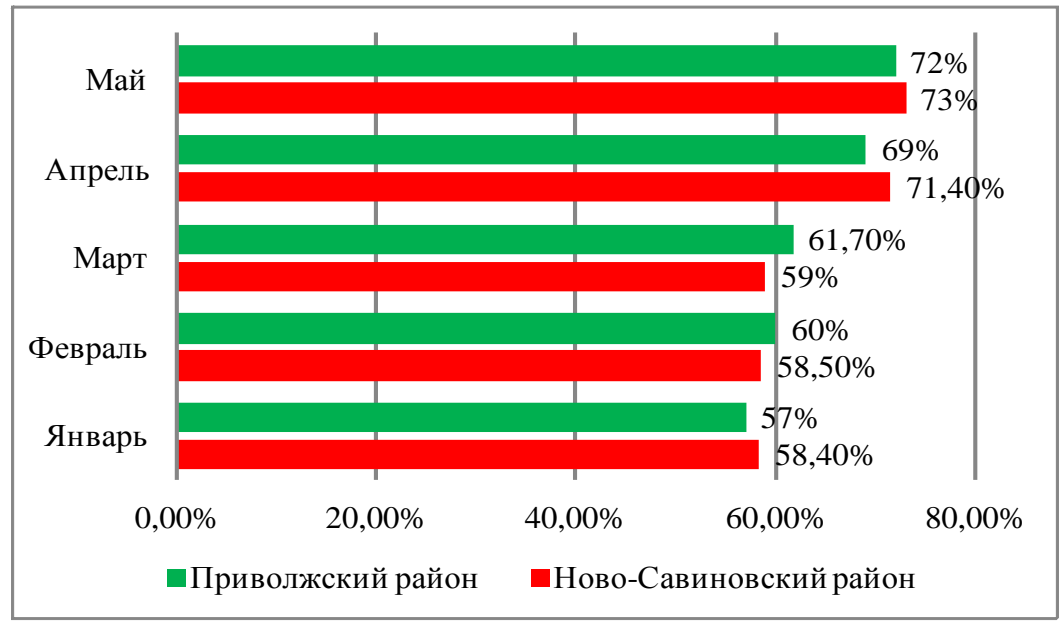

Рис. 1. Динамика обращений граждан через Портал государственных и муниципальных услуг РТ

Согласно проведенному опросу, 95\% граждан положительно относится к деятельности ЦЗН, направленной на развитие применения современных информационных технологий.

Мы изучили применение современных информационных технологий специалистами ЦЗН - экспертное интервью со специалистами этих учреждений. Согласно проведенному опросу:

- 100\% сотрудников положительно относятся к внедрению ИТ в работе ЦЗН;

- серьезных сбоев в работе не происходит;

- специалисты отмечают, «без информатизации нет будущего»;

- основные трудности они видят в сохранении прежнего объема «бумажной» работы и создания, таким образом, дополнительной нагрузки;

- было высказано предложение перенесения всего процесса работы в электронный вид.

Перевод всего процесса работы в электронный вид:

- сократило бы время обслуживания одного клиента;

- увеличение производительности труда работников ЦЗ;

- минимизирует человеческий фактор;

- уменьшается риск получения государственных услуг обманным путем;

- позволяет координировать деятельность различных ведомств, связанных с деятельностью ЦЗ. 
Специалисты на стороне ухода от бюрократических процедур в сторону непосредственного взаимодействия с клиентом.

При информатизации, переводе всего процесса работы в электронный вид, могут возникнуть следующие сложности:

- технические неполадки в работе системы;

- повреждение системы;

- тяжело обеспечить безопасность, конфиденциальность данных;

- требуется постоянное усовершенствование материальнотехнической базы, в связи с технологическими и техническими изменениями информационных технологий;

- человеческий фактор - постоянное обучение персонала.

По результатам опроса клиентов ЦЗ, безработных граждан и специалистов можно сделать вывод, что все пользователи положительно оценивают использование информационных технологий в деятельности ЦЗ при оказании социальных услуг. Поставленная перед нами цель была достигнута.

По итогам проведенного опроса клиентов и специалистов ЦЗН можем сделать следующие выводы:

1. Большинство респондентов $(95 \%)$ поддерживают внедрение в ЦЗН системы электронной очереди.

2. $28 \%$ граждан ни разу не воспользовались терминалом вакансий.

3. $90 \%$ респондентов информированы о возможности работы с официальным сайтом ЦЗН.

4. О возможности записи на прием к специалисту через Портал государственных и муниципальных услуг РТ знают $80 \%$ респондентов.

5. Все специалисты положительно относятся к внедрению информационных технологий в работе ЦЗН.

В результате анализа результатов проведенного исследования мы предлагаем следующие рекомендации:

1. Внедрить при постановке на учет автоматическое размещение резюме безработного гражданина на официальном сайте ЦЗН, где его могут просматривать работодатели, что повысит качество оказания социальных услуг 
по трудоустройству, предоставит безработному гражданину больше возможностей для успешного трудоустройства.

Для этого необходимо внесение в «Заявление-анкету о предоставлении гражданину государственной услуги содействия в поиске подходящей работы» пункта о согласии безработного гражданина на публикацию его резюме. Работодатель в режиме реального времени сможет связаться с кандидатом, уточнить и получить все сведения о нём. Безработный гражданин также сможет получить дополнительную информацию, ответы на возникающие вопросы.

2. Внести следующее дополнение в программную оболочку терминалов вакансий и электронной очереди: на экране терминала клиенту предлагается ответить на один или несколько вопросов по качеству обслуживания и работы с терминалом.

Полученные данные позволят оперативно оценивать качество, сделать выводы и вносить корректировки в используемый программный продукт. Кроме того результаты могут дополняться данными других систем и поступать заинтересованным лицам в виде готовых отчетов. Сформированные отчеты откроют наиболее полную картину реального качества сервиса.

3. Повысить информированность граждан о возможности записи на прием через Портал государственных и муниципальных услуг РТ:

- разместить в местах массового скопления людей (ЦЗН, КЦСОН, ПФР, поликлиники, больницы, метро, учебные заведения и др.) брошюры, буклеты, листовки, информационные стенды, бегущая строка, информирующие, об этой возможности оказания и получения социальных услуг;

- пропаганда, информирование специалистами социальных учреждений Министерства труда, занятости и социальной зашиты РТ клиентов о возможности записи на прием к специалисту через портал государственных и муниципальных услуг РТ.

Всё это поможет повысить эффективность деятельности Центров занятости, каждого работника, качество обслуживания клиентов, ускорит процессы обслуживания и трудоустройства клиентов, позволит усовершенствовать всю работу при оказании социальных услуг. 


\section{Литература:}

1. Бехманн Г. Современное общество. Общество риска, информационное общество, общество знаний / Г. Бехманн. - М.: Логос, 2010. - 248 с.

2. Ветрова Е.Н. Государственная информационная политика как фактор повышения эффективности государственного управления: автореф. дис. ... канд. полит. наук / Е.Н. Ветрова. - Орел: Российская академия народного хозяйства и государственной службы при Президенте РФ, 2014. - 26 с.

3. Гасумова С.Е. Информационные технологии в социальной сфере: учебное пособие / С.Е. Гасумова. - 3-е изд., перераб. и доп. - М.: Дашков и К, 2012. $-248 \mathrm{c}$.

4. За цифрами - граждане, семьи, судьбы / Под ред. В. Котоврасова // Служба занятости. 2016. № 4. - С. 6-17.

5. Закон Российской Федерации от 19 апреля 1991 года № 1032-1 «О занятости населения в Российской Федерации»: [электронный ресурс]. Режим доступа: Информационно-правовой ресурс http://www.consultant.ru. (Дата обращения: 02.05.2016).

6. Итоги 2015 года в сфере социальной защиты населения. Отчет Министерства труда и социальной защиты РФ // Социальная работа. Научно популярный журнал. 2016. № 1. - С. 2-3.

7. Кирпичева А.Ю. ИКТ в госсекторе России: итоги и перспективы / А.Ю. Кирпичева, В.И. Горелова // Перспективы развития информационных технологий. 2015. № 24. - С. 99-104.

8. Конституция Российской Федерации: [электронный ресурс]. Режим доступа: Информационно-правовой ресурс http://www.consultant.ru (Дата обращения: 05.04.2016). 
9. Кузьмина Н.Е. Оптимизация функций государственного управления в области мер социальной поддержки граждан / H.Е. Кузьмина // Социальная работа. 2016. № 3. - С. 71-76.

10. Министерство труда и социальной защиты Российской Федерации: [электронный ресурс]. Режим доступа: http://www.rosmintrud.ru. (Дата обращения: 20.04.2016).

11. Никифоров Н.А. Инновационная модель управления информационными потоками в сфере оказания государственных электронных услуг (на примере Республики Татарстан): автореф. дис. ... канд. эконом. наук. - М.: Институт социальных и гуманитарных знаний (г. Казань), 2011. - 14 с.

12. Общероссийская база вакансий Работа в России: [электронный ресурс]. Режим доступа: http://www.trudvsem.ru. (Дата обращения: 05.03.2016).

13. Паврозин Д.А. Управление занятостью населения в регионе / Д.А. Паврозин // Перспективы развития информационных технологий. 2016. № 28. - C. 61-65.

14. Портал государственной службы занятости Республики Татарстан: [электронный pecypc]. Режим доступа: http://www.tatartrud.ru. (Дата обращения 05.03.2016).

15. Портал государственных услуг службы занятости: [электронный ресурс]. Режим доступа: http://uslugi.tatartrud.ru. (Дата обращения 05.03.2016).

16. Федеральный закон от 27.07.2006 № 149-Ф3 «Об информации, информационных технологиях и о защите информации»: [электронный pecypc]. Режим доступа: Информационно-правовой ресурс http://www.consultant.ru. (Дата обращения: 18.04.2016).

17. Федеральный закон от 28.12.2013 № 442-Ф3 «Об основах социального обслуживания граждан в Российской Федерации»: [электронный ресурс]. Режим доступа: Информационно-правовой ресурс http://www.consultant.ru. (Дата обращения: 05.04.2016). 
18. Численность безработных граждан: ежемесячный отчет Министерства труда, занятости и социальной защиты Республики Татарстан. Открытый Татарстан: [электронный ресурс]. Режим доступа: http://open.tatarstan.ru. (Дата обращения: 20.04.2016).

19. Электронный работодатель: [электронный ресурс]. Режим доступа: http://er.regiontrud.ru. (Дата обращения: 05.03.2016).

20. http://www.rosmintrud.ru - Министерство труда и социальной защиты Российской Федерации;

21. http://minsvyaz.ru - Министерство связи и массовых коммуникаций Российской Федерации;

22. http://mtsz.tatarstan.ru - Министерство труда, занятости и социальной защиты Республика Татарстан;

23. http://mic.tatarstan.ru - Министерство информатизации и связи Республики Татарстан;

24. http://www.gks.ru - Федеральная служба государственной статистики;

25. https://uslugi.tatarstan.ru - Портал государственных и муниципальных услуг Республики Татарстан;

26. http://www.kazantrud.ru - Сайт ГКУ «Центр занятости населения города Казани». 